\title{
PENGARUH FAKTOR INTERNAL DAN EKSTERNAL TERHADAP RETURN SAHAM PERBANKAN YANG GO PUBLIC YANG TERCATAT DI BURSA EFEK INDONESIA PADA TAHUN 2014 - 2019
}

\author{
Astohar $^{1}$, Dhian AMS ${ }^{2}$, Sari Rahmadhani ${ }^{3}$ \\ 1,2,3 STIE Totalwin, Semarang \\ Corresponding author : astohardemak@gmail.com
}

\begin{abstract}
ABSTRAK
Rata - rata return saham perbankan pada 2014 sampai dengan 2019 tidak selalu menunjukkan return yang positif. Pada tahun 2015, 2018 dan 2019 menunjukkan ratarata return saham perbankan yang negative. Penelitian ini pengembangan dari penelitian sebelumnya atau berdasarkan agenda mendatang dengan menambahkan variable eksternal yaitu inflasi, pertumbuhan ekonomi dan tingkat bunga SBI. Penelitian ini dilakukan pada perbankan yang go public di Bursa Efek Indonesia tahun 2014-2019. Penelitian ini menggunakan data dari 27 bank dari 43 perbankan yang memenuhi kriteria sampel. Alat analisis yang digunakan adalah regresi linier berganda. Hasil penelitian adalah return on equity (ROE) mempunyai pengaruh yang positif signifikan terhadap return saham pada Perbankan yang go public di BEI. Variable inflasi terbukti mempunyai pengaruh yang negative signifikan terhadap return saham pada perbankan yang go public di BEI. Variable loan to deposit ratio (LDR), net interest margin (NIM), pertumbuhan ekonomi dan suku bunga SBI tidak terbukti mempunyai pengaruh yang signifikan terhadap return saham perbankan yang go public di Bursa Efek Indonesia (BEI).
\end{abstract}

Kata Kunci : ROE, LDR, NIM, Inflasi, Pertumbuhan, SBI dan Return Saham

\section{PENDAHULUAN}

Dampak dari perkembangan perekonomian Indonesia pada saat ini adalah semakin penting dan berperannya industri perbankan. Perbankan menjadi sektor yang sangat penting dan diperlukan dalam mendukung seluruh kegiatan ekonomi atau kegiatankegiatan lainnya yang ada urusan dengan penyaluran dana di Indonesia. Melalui fungsinya sebagai perantara untuk menerima atau menyalurkan pendanaan dari pihak-pihak yang memiliki dana uang berlebih untuk disimpan di bank dan menyalurkan kembali kepada orang yang mebutuhkan dana untuk modal usaha atau lainnya (Sunaryo, 2020).

Persaingan dalam dunia usaha saat ini semakin kompetitif dan lebih ketat, yang mana kelangsungan hidup dan kesempatan berkembangan perusahaan sangat dipengaruhi oleh ketersediaan dana dan akses ke sumber dana. Peran sektor perbankan yang vital tersebut didukung oleh sumber pendanaan yang cukup besar dari berbagai sumber (internal ataupun eksternal). Salah satu sumber dana eksternal bagi perusahaan adalah pasar modal, dengan menerbitkan surat berharga di pasar modal (Juliana dkk, 2019). Pasar modal memberikan kesempatan perusahaan untuk bersaing secara sehat dalam rangka menarik minat investor agar menanamkan modalnya diperusahaannya (Antari, dkk, 2020).

Pemodal (investor) secara umum melakukan pengamatan dan penilaian terlebih terhadap perusahaan yang akan dipilih dengan memantau laporan keuangan perusahaan- 
perusahaan tersebut terutama perusahaan yang sudah go public. Melalui laporan keuangan tersebut dapat diketahui kinerja perusahaan dalam menjalankan kegiatan usaha dan kemampuan perusahaan dalam mendayagunakan aktivitas usahanya secara efisien dan efektif serta faktor di luar perusahaan ekonomi, politik, finansial dan lain-lain (Rasmin 2007 dalam Arista dan Astohar, 2012). Lebih lanjut Juliana dkk (2020) laporan keuangan merupakan sarana investor untuk mengetahui posisi keuangan perusahaan dan dapat digunakan untuk pembuatan keputusan investasi yang tepat.

Investor menginvestasikan dananya dengan membeli saham pada suatu perusahaan yang tercatat di BEI untuk memperoleh return atau pendapatan dari investasi yang dilakukannya. Bagi investor yang telah menanamkan dananya untuk membeli saham pada sector perbankan berharap akan memberikan suatu imbalan hasil (return). Imbalan tersebut dapat berupa pemberian dividen dan atau mendapatkan capital gain dari peningkatan harga saham yang dimiliki. Investor harus memperhatikan kinerja perusahaan perbankan untuk target keuntungan berupa deviden atau return saham atau capital gain (Sunaryo, 2020).

Menurut Yudistira dan Adiputra (2020) banyak faktor yang berpengaruh terhadap return saham seperti faktor internal (terkait kinerja perbankan) atau pun dari faktor- faktor yang eksternal seperti kondisi perekonomian dan kebijakan dari negara. Hasil penelitian yang dilakukan oleh Dewi (2019) memberikan hasil bahwa return saham dipengaruhi oleh loan to deposit ratio (LDR), net interest margin (NIM) dan return on asset (ROA). Dewi (2019) memberikan rekomendasi untuk menambah variable eksternal seperti nilai pertumbuhan ekonomi, tingkat inflasi dan suku bunga Bank Indonesia.

Loan to deposit ratio (LDR) adalah perbandingan atau rasio antara seluruh jumlah kredit yang diberikan bank dengan dana yang diterima oleh bank (Gantino dan Maulana, 2013). Loan to deposit ratio (LDR) mempunyai pengaruh yang positif dan signifikan terhadap return saham (Juliana dkk, 2019). Hal dapat diartikan apabila perbankan menyalurkan kredit dengan tetap memperhatikan jumlah dana pihak ketiga yang masuk (tabungan, deposito dan giro) akan berdampak pada peningkatan return saham (Juliana dkk, 2019). Hasil penelitian ini bertolak belakang dengan penelitian yang dilakukan oleh Purnamasari dkk (2017) serta dari Setyarini dan Rahyuda (2017) tidak ada pengaruh yang signifikan dan lebih lanjut Sambul dkk (2016) dimana peningkatan pemberian kredit yang melebihi jumlah dana pihak ketiga yang masuk akan berdampak pada penurunan return saham.

Return on equity (ROE) adalah perbandingan antara laba setelah pajak dibagi dengan modal sendiri atau dengan kata lain rasio yang mengukur seberapa banyak keuntungan yang menjadi hak pemilik modal sendiri (Hendayana dan Nurlina, 2020). Hasil penelitian dari Hendayana dan Nurlina (2020) menunjukkan bahwa return on equity (ROE) mempunyai pengaruh yang positif dan signifikan terhadap return saham. Hasil penelitian ini didukung oleh Purnamasari dkk (2017) dimana peningkatan return on equity (ROE) berdampak pada peningkatan tingkat kembalian saham. Hasil penelitian ini berbeda dengan penelitian yang Yudistira dan Adiputra (2020) bahwa return on equity (ROE) mempunyai pengaruh yang negatif dan signifikan terhadap return saham.

Net interest margin (NIM) adalah rasio yang digunakan untuk menilai kemampuan manajer dalam pengelolaan akiva produktif sehingga sanggup mengghasilkan bunga bersih. Semakin tinggi rasio NIM, yg berarti semakin tinggi profitabilitas bank, hal ini secara tak langsung akan meninngkatkan harga saham. Hasil penelitian dari Kurniadi (2012) menunjukkan bahwa Net interest margin (NIM) mempunyai pengaruh yang positif terhadap return saham. Hasil tersebut menunjukkan bahwa peningkatan pendapatan bunga bersih akan berdampak pada peningkatan return saham perbankan. Hasil penelitian ini bertolak belakang dengan 
penelitian dari Yudistira dan Saputra (2020) dimana Net interest margin (NIM) tidak mempunyai pengaruh terhadap return saham perbankan.

Kondisi perekonomian secara makro sangat dapat mempengaruhi aktivitas operasional perusahaan atau perbankan. Tingkat Pengetahuan investor dalam pemahaman dan predikisi kondisi ekonomi makro di masa akan datang berguna dalam pengambilan keputusan investasi yang menguntungkan (Amrilah, 2016). Pertumbuhan ekonomi mempunyai pengaruh negative terhadap return saham (Adiyadnya, dkk 2016). Hal ini menunjukkan bahwa pertumbuhan ekonomi dapat menurunkan tingkat return yang diterima oleh Investor (Amrilah, 2016). Hasil penelitian tersebut bertolak belakang dengan penelitian yang dilakukan oleh Sembiring (2017) dimana pertumbuhan ekonomi di negara tidak mempunyai dampak terhadap return saham yang diterima oleh investor.

Inflasi adalah kenaikan tingkat harga secara umum dari barang atau komoditas dan jasa selama periode waktu tertentu Karim (2007 dalam Safuridar dan Asyuratama, 2018). Inflasi dapat dianggap sebagai suatu fenomena moneter karena terjadi penurunan nilai unit perhitungan terhadap suatu komoditas. Hasil penelitian dari Inflasi mempunyai pengaruh negative terhadap return saham (Adiyadnya, 2016). Hal ini menunjukkan tingginya atau adanya peningkatan inflasi akan berdampak terhadap penurunan return saham (Amrillah, 2016) dan (Juliana dkk, 2019). Hasil ini bertolak berlakang dengan penelitian yang dilakukan oleh Suriyani dan Sudartha (2018) dan penelitian Yudistira dan Adiputra (2020), dimana tidak ada pengaruh yang signifikan antara inflasi terhadap return saham perbankan.

Kebijakan tingkat suku bunga merupakan kebijakan moneter yang diputuskan oleh pemerintah untuk mendorong pertumbuhan ekonomi perbankan (Nanga, 2007 dalam Safurida dan Asyuratama, 2018). Hasil penelitian dari Nurlina (2017) menunjukkan bahwa tingkat suku bunga Bank Indonesia mempunyai pengaruh yang positif dan signifikan terhadap return saham. Hal ini menunjukkan peningkatan tingkat suku Bunga mengindikasi perekonomian sedang stabil, karena kemampuan dari para pelaku ekonomi yang mampu dalam pembayaran bunga yang ditetapkan akan berdampak pada penerimaan atau return saham. Hasil penelitian bertolak belakang dengan hasil penelitian dari Suriyani dan Sudiartha (2018) dan yaitu tingkat bunga Bank Indonesia tidak berdampak pada return saham

Obyek penelitiannya adalah pada perbankan yang go public di Indonesia karena perkembangan return saham selaam 6 tahun mengalami fluktuatif (naik dan turun).

Tabel 1

Rata - Rata Return Saham Perbankan Selama 6 Tahun (2014 - 2019)

Tahun Rata - rata Return Saham

\begin{tabular}{ll}
\hline 2014 & 0,16 \\
2015 & $-0,15$ \\
2016 & 0,39 \\
2017 & 0,28 \\
2018 & $-0,04$ \\
2019 & $-0,02$
\end{tabular}

Rata - rata return saham dari tahun 2014 sampai dengan 2019 menunjukkan ada beberapa kali negative (penurunan). Return saham mengalami rata - rata minus selama 
periode penelitian terjadi 3 kali yaitu pada tahun 2015, 2018 dan 2019. Pada tahun 2015 rata- ratanya adalah - 0,15 pada tahun 2018 rata - ratanya - 0,04 dan pada tahun 2019 rata - rata nya sebesar - 0,02. Hal ini menjadi pertimbangan pemilihan obyek penelitian yang masih pada sektor perbankan yang yg public di Indonesia.

\section{LANDASAN TEORI DAN PENGEMBANGAN HIPOTESIS Teori signaling}

Isyarat atau signal adalah suatu tindakan yang diambil perusahaan untuk memberi petunjuk bagi investor tentang bagaimana manajemen memandang prospek perusahaan. Sinyal ini berupa informasi mengenai apa yang sudah dilakukan oleh manajemen untuk merealisasikan keinginan pemilik (Brigham dan Hauston (2001). Informasi yang dikeluarkan oleh perusahaan merupakan hal yang penting, karena pengaruhnya terhadap keputusan investasi pihak diluar perusahaan. Dalam teori ini menyatakan bahwa perusahaan yang berkualitas baik dengan sengaja akan memberikan sinyal pada pasar yang berupa informasi. Pasar diharapkan dapat membedakan perusahaan yang berkualitas baik dan buruk. Sinyal dari perusahaan tersebut efektif harus dapat ditangkap pasar dan dipersepsikan baik, juga tidak mudah ditiru oleh perusahaan yang berkualitas buruk (Sccott dan Megginson, 1987 dalam Arista dan Astohar, 2012).

Teori signaling merupakan sinyal informasi yang dibutuhkan oleh para investor untuk menentukan apakah investor tersebut akan menanamkan sahamnya. Teori ini berfungsi memberikan kemudahan bagi investor untuk mengembangkan sahamnya yang dibutuhkan oleh manajer perusahaan dalam menentukan arah atau prospek kedepannya (Nariati, 2018). Informasi yang dipublikasikan sebagai suatu pengumuman akan memberikan sinyal bagi investor dalam pengambilan keputusan investasi. Jika pengumuman tersebut mengandung nilai positif, maka diharapkan pasar akan bereaksi pada waktu pengumuman tersebut diterima oleh pasar. Reaksi pasar ditunjukkan dengan adanya perubahan volume perdagangan saham yang dikarenakan investor menggunakan informasi yang ada untuk dianalisis sehingga terjadi perubahan volume perdagangan saham (Sunardi, 2010).

\section{Pasar Modal, Saham dan Return Saham}

Pasar modal (capital market) merupakan pasar untuk berbagai instrumen keuangan jangka panjang yang bisa diperjualbelikan, baik surat utang (obligasi), ekuiti (saham), reksa dana, instrumen derivatif maupun instrumen lainnya. Saham (stock atau share) dapat didefinisikan sebagai tanda penyertaan atau pemilikan seseorang atau badan dalam suatu perusahaan atau perseroan terbatas. Saham berwujud selembar kertas yang menerangkan bahwa pemilik kertas adalah pemilik perusahaan yang menerbitkan surat berharga tersebut. Return merupakan hasil yang diperoleh dari investasi (Jogiyanto,2014).

\section{Return on Equity (ROE)}

Return on equity ( $R O E$ ) adalah rasio yang mengukur seberapa banyak keuntungan yang menjadi hak pemilik modal sendiri (Hendayana dan Nurlina, 2020). Semakin besar tingkat laba bersih yang dicapai, maka nilai pengembalian atas modal (ROE) perusahaan pun semakin tinggi, sehingga return yang diterima pemegang saham juga akan tinggi. Return on equity (ROE) adalah rasio yang digunakan untuk mengukur keberhasilan perusahaan dalam menghasilkan laba bagi para pemegang saham juga sebagai representasi dari kekayaan pemegang saham atau nilai perusahaan (Rahmani, 2019). Hasil penelitian dari Rahmani (2019) dan didukung oleh Hendayana dan Nurlina (2020) yang menunjukkan bahwa return on equity ( $R O E)$ terbukti berpengaruh positif dan signifikan terhadap return saham. 
$\mathrm{H}_{1}$ : Return on equity (ROE) berpengaruh positif signifikan terhadap return saham Perbankan yang go public

\section{Loan to Deposit Ratio (LDR)}

Loan to deposit ratio $(L D R)$ yaitu perbandingan antara kredit yang diberikan dengan dana pihak ketiga (Taswan, 2010). Menurut Dendawijaya (2005) Loan to Deposit Ratio (LDR) menunjukkan rasio antara seluruh jumlah kredit yang diberikan bank dengan dana yang diterima oleh bank. Hasil penelitian dari Gantino dan Maulana (2013) bahwa loan to deposit ratio $(L D R)$ mempunyai pengaruh yang negatif dan signifikan terhadap return saham perbankan. Hasil penelitian ini sejalan dengan Sambul dkk (2016) bahwa peningkatan rasio pemberian kredit dibanding dengan dana pihak ketiga yang masuk berdampak pada penurunan pengembalian saham berupa return dari investor.

$\mathrm{H}_{2}$ : Loan to deposit ratio (CAR) berpengaruh negative signifikan terhadap return saham Perbankan yang go public

\section{Net Interest Margin (NIM)}

Net Interest Margin (NIM) merupakan pendapatan bunga kredit dikurangi biaya bunga simpanan terhadap outstanding kredit (Dewi, 2019). Hasil Penelitian dari Kurniadi (2012) menunjukkan bahwa net interest margin (NIM) berpengaruh positif dan sginfikan terhadap return saham. Lebih lanjut Harahap dan Hairunnisah (2017) bahwa pendapatan bersih bunga dari perbankan dapat berdampak pada signal positif dari investor kepada perbankan berkenaan dengan kinerja perbankan tersebut, dampak yang ditimbulkan adalah permintaan saham perbankan tersebut mengalami peningkatan, sehingga return saham juga mengalami peningkatan. Berdasarkan agumen diatas dapat diajukan hipotesis ke 3 sebagai berikut.

$\mathrm{H}_{3}$ : Net Interest Margin (NIM) berpengaruh positif signifikan terhadap return saham Inflasi

Perbankan yang go public

Inflasi menurut Hasyim (2017) menyatakan bahwa inflasi adalah gejala ekonomi yang menunjukkan naiknya tingkat harga secara umum yang berkesinambungan. Lebih lanjut menurut Panennungi dan Novia (2017 dalam Zakiyah 2019) bahwa inflasi merupakan peningkatan harga-harga secara umum dalam jangka waktu tertentu. Hasil penelitian dari Zakiyah (2019) menunjukkan bahwa inflasi mempunyai pengaruh yang negative terhadap return saham. Hal ini menunjukkan inflasi membuat permintaan saham akan menurun, sehingga berdampak pada penurunan permintaan saham (Safuridar dan Asyuratama, 2018). Sehingga terjadinya inflasi atau peningkatna inflasi akan berdampak pada penurunan return saham (Juliana dkk, 2019). Berdasarkan argument diatas dapat diajukan hipotesis sebagai berikut :

$\mathrm{H}_{4}$ : Net Interest Margin (NIM) berpengaruh positif signifikan terhadap return saham Perbankan yang go public

\section{Pertumbuhan Ekonomi}

Pertumbuhan ekonomi atau Produk Domestik Bruto (PDB) atau Gross Domestic Product (GDP) diartikan sebagai nilai pasar dari semua barang jadi dan jasa yang diproduksi di suatu Negara dalam kurun waktu tertentu (Mankiw, 2006). Produk Domestik Bruto (PDB) dibagi atas PDB Riil (real GDP) yang merupakan nilai produksi seluruh barang dan jasa pada harga konstan, dan PDB Nominal (nominal GDP) yang merupakan nilai produksi seluruh barang dan jasa berdasarkan harga yang tengah berlaku (Adiyadnya dkk, 20160). Hasil penelitian dari Amrillah (2016) menunjukkan bahwa pertumbuhan 
ekonomi berpengaruh negative terhadap return saham. Hasil ini menunjukkan bahwa pertumbuhan ekonomi atau PDB yang meningkat justru menurunkan pendapatan saham oleh para investor di perbankan (Adiyadnya dkk, 2016). Berdasarkan hasil penelitian terdahulu dapat diajukan hipotesis sebagai berikut :

$\mathrm{H}_{5}$ : Pertumbuhan ekonomi berpengaruh positif signifikan terhadap return saham Perbankan yang go public

\section{Tingkat Bunga Sertifikat Bank Indonesia (SBI)}

Menurut Ismail (2018) bahwa bunga dapat diartikan sebagai harga yang harus dibayar oleh bank dan/atau nasabah sebagai balas jasa atas transaksi antara bank dan nasabah. Tingkat suku bunga SBI adalah tingkat pembayaran atas pinjaman atau investasi lain, di atas perjanjian pembayaran kembali, yang dinyatakan dalam persentase yang ditetapkan Bank Indonesia dengan mengeluarkan Sertifikat Bank Indonesia (Maryanne, 2009). Hasil penelitian dari Nurlina (2017) menunjukkan bahwa tingkat suku bunga SBI mempunyai pengaruh yang negative dan signifikan terhadap return saham. Hal ini menunjukkan peningkatan tingkat suku Bunga mengindikasi perekonomian sedang stabil, karena kemampuan dari para pelaku ekonomi yang mampu dalam pembayaran bunga yang ditetapkan akan berdampak pada penerimaan atau return saham. Berdasarkan argument diatas dapat diajukan hipotesis sebagai berikut.

$\mathrm{H}_{6}$ : Suku bunga berpengaruh positif signifikan terhadap return saham Perbankan yang go public

\section{MODEL PENELITIAN}

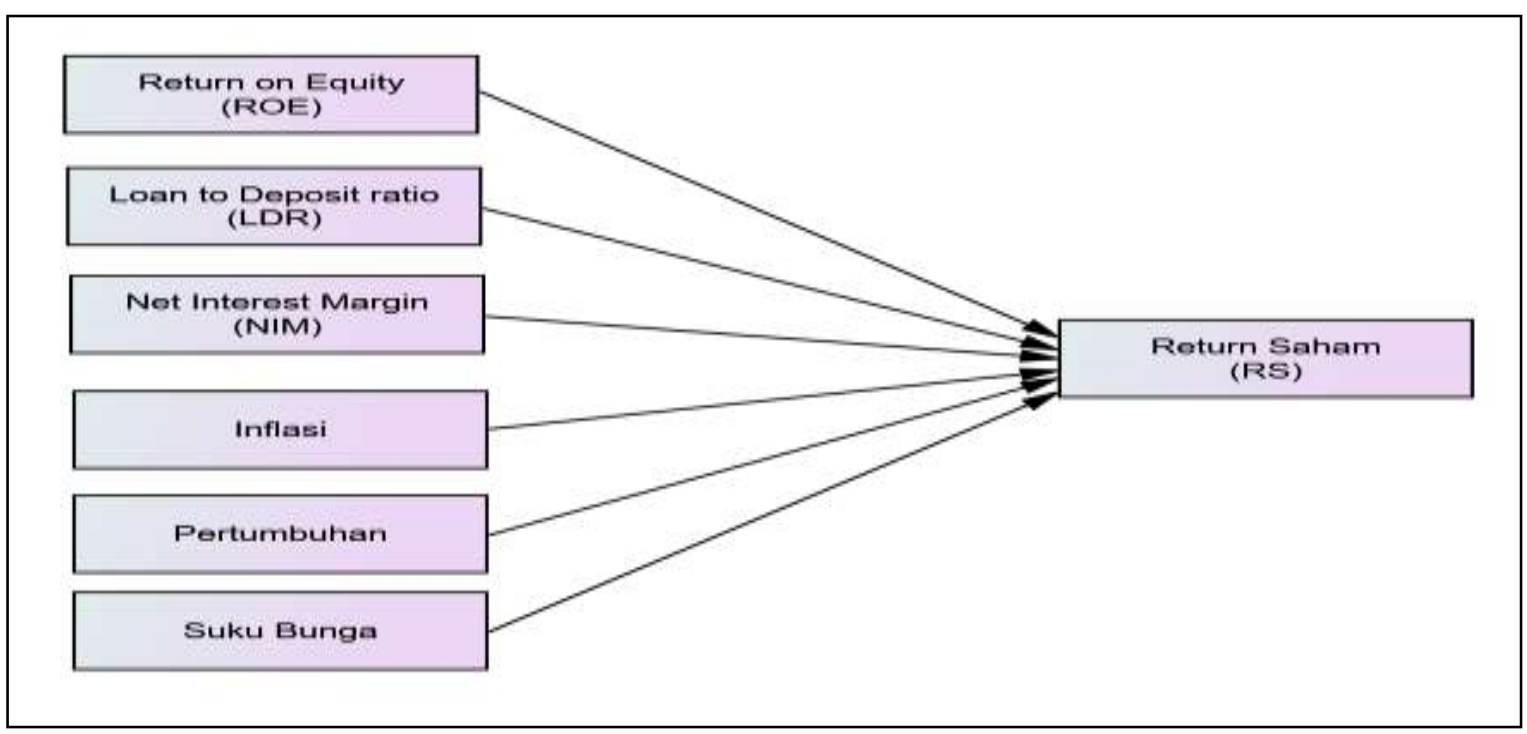

Gambar 1 Kerangka Pikir Penelitian

\section{METODE PENELITIAN}

\section{Populasi dan Sampel}

Populasi dalam penelitian ini adalah perbankan yang go public di Bursa Efek Indonesia telah terdaftar di Bursa Efek Indonesia sampai dengan tahun 2019 yaitu sebanyak 43 bank go public. Metode pengambilan atau pmilihan sampel menggunakan metode purposive sampling (Sugiyono, 2019). Pengumpulan data menggunakan panel selama 6 
tahun periode penelitian. Setelah melalui pertimbangan terdapat 16 bank go public yang tidak bisa digunakan sebagai sampel dengan alasan, go public setelah tahun 2013 dan data tidak tersedia secara lengkap selama periode penelitian. Sampel yang digunakan dalam penelitian ini adalah sebanyak 27 Perbankan atau 162 observasi. Setelah melalui tahapan screening dan pemenuhan normalitas terdapat 8 observasi yang dikeluarkan, sehingga observasi akhir yang digunakan sebanyak 154 observasi. Data yang digunakan adalah berupa laporan keuangan publikasi tahunan yang diterbitkan oleh Bank Indonesia yang diperoleh dari WEB OJK dari periode tahun 2014 sampai tahun 2019. Sumber data yang digunakan ini diperoleh melalui penelusuran dari media internet dari www. idx.go.id (ringkasan perusahaan). Metode pengumpulan data yang digunakan yaitu melalui studi pustaka dari direktori perusahaan go publik dan situs resmi tiap perusahaan.idx.go.id. serta situs - situr resmi lainnya yang dijadikan sampel.

\section{Alat Analisis Data}

\section{Uji Persamaan Regresi Ganda}

Analisis regresi linier berganda adalah pengaruh secara linier antara dua atau lebih variabel bebas (independen) dengan satu variabel dependen, yaitu pengaruh dari return on equity (ROE), loan to deposit ratio (LDR), net interest margin (NIM), inflasi, pertumbuhan ekonomi dan suku bunga SBI terhadap return saham perbankan yang go public di Bursa Efek Indonesia (BEI) (Astohar, 2013). Sebelum dilakukan pengujian regresi data juga dilakukan pengujian normalitas, penyimpangan asumsi klasik dan pengujian hipotesis. Persamaan regresi pada penelitian ini terdapat dua model. yaitu sebagai berikut :

$Y_{1}=a+b_{1} X_{1}+b_{2} X_{2}+b_{3} X_{3}+b_{4} X_{4}+b_{5} X_{5}+b_{6} X_{6}$

Dimana :

$\begin{array}{ll}\mathrm{Y}_{1} & \text { : Return saham } \\ \mathrm{X}_{1} & \text { : ROE } \\ \mathrm{X}_{2} & \text { : LDR } \\ \mathrm{X}_{3} & \text { : NIM } \\ \mathrm{X}_{4} & \text { : Inflasi } \\ \mathrm{X}_{5} & \text { : pertumbuhan ekonomi } \\ \mathrm{X}_{6} & \text { : Tingkat bunga SBI }\end{array}$

\section{Uji Koefisien Determinasi}

Koefisien determinan pada penelitian ini digunakan untuk melihat berapa persen dari variasi variabel terikat dijelaskan variabel bebas. Pada penelitian ini koefisien determinasi adalah mengetahui seberapa besar variasi return saham Bank Go Public dapat diterangkan oleh variasi dari dari return on equity (ROE), loan to deposit ratio $(L D R)$, net interest margin (NIM), inflasi, pertumbuhan ekonomi dan suku bunga SBI (Ghozali, 2018).

\section{HASIL DAN PEMBAHASAN}

Tabel 1 : Deskriptif Statistik

Descriptive Statistics

\begin{tabular}{lrrrrr}
\hline & N & Minimum & Maximum & \multicolumn{1}{c}{ Mean } & Std. Deviation \\
\hline ROE & 154 & $-48,91$ & 31,22 & 8,3819 & 11,20962 \\
LDR & 154 &, 00 & 169,76 & 87,3704 & 16,67331 \\
NIM & 154 &, 87 & 11,98 & 5,1305 & 2,04260 \\
Inflasi & 154 & 4,56 & 7,54 & 6,0632 & 1,13735 \\
pertumb & 154 & 4,88 & 5,17 & 5,0303 &, 08673 \\
Bunga & 154 & 3,03 & 6,42 & 4,4081 & 1,44859 \\
R_Saham & 154 &,- 8039 & 1,2056 &, 068136 &, 3601022 \\
Valid N (listwise) & 154 & & & & \\
\hline
\end{tabular}


Pada variable return saham Bank Go Public $(R S)$ yang rata-ratanya adalah sebesar 0,068. Berdasarkan rata - rata, Bank Go Public masuk dalam kategori yang baik $(0,07 \%)$, hal ini ditandai dengan rata - rata return saham Bank Go Public masih diatas 0 (positif). Berdasarkan data yang diperoleh return saham Bank Go Public terendah pada periode penelitian yaitu sebesar - 0,81\% yaitu pada Bank Rakyat Indonesia, Tbk pada tahun 2015. Return saham Bank Go Public tertinggi adalah pada Bank Victoria International, Tbk pada tahun 2017 yaitu sebesar 1,21.

Pada variabel return on equity (ROE) ini menunjukkan bahwa berdasarkan rata rata Bank Go Public masuk dalam kategori yang sehat, hal ini ditandai dengan rata - rata return on equity ( $R O E$ ) masih dikisaran $8,34 \%$. Return on equity (ROE) yang paling rendah pada penelitian yaitu sebesar - 48,91\% adalah pada Bank MNC Internasional, Tbk pada tahun 2017. Rasio return on equity (ROE) yang tertinggi adalah pada Bank Rakyat Indonesia, Tbk pada tahun 2014 yaitu sebesar 31,22\%.

Pada variabel loan to deposit ratio $(L D R)$ ini menunjukkan bahwa berdasarkan rata - rata Bank Go Public masuk dalam kategori yang sehat, hal ini ditandai dengan rata - rata loan to deposit ratio (LDR) masih dikisaran 87,37 \% (Ketentuan Bank Indonesia $85 \%$ sampai dengan $110 \%$ ). Loan to deposit ratio (LDR) yang paling rendah pada penelitian yaitu sebesar 51,57 \% adalah pada Bank National Nobu, Tbk pada tahun 2017. Rasio loan to deposit ratio $(L D R)$ yang tertinggi adalah pada Bank China Construction Bank Indonesia pada tahun 2014 yaitu sebesar 169,76\%.

Pada variabel net interest margin (NIM) ini menunjukkan bahwa berdasarkan rata rata Bank Go Public masuk dalam kategori yang sehat, hal ini ditandai dengan rata - rata net interest margin (NIM) masih dikisaran 5,13\%. Net interest margin (NIM) yang paling rendah pada penelitian yaitu sebesar 4,62 \% adalah pada Bank Rakyat Indonesia Agroniaga, Tbk pada tahun 2014. Rasio loan to deposit ratio (LDR) yang tertinggi adalah pada Bank Tabungan Pensiunan Nasional, Tbk pada tahun 2016 yaitu sebesar 11,98 \%.

Pada variabel kondisi eksternal menunjukkan bahwa inflasi ini menunjukkan bahwa selama enam tahun (2014 sampai dengan 2019) pada kategori yang tinggi, hal ini ditandai dengan rata - rata inflasi masih dikisaran $6,06 \%$. Inflasi yang paling rendah pada tahun 2017 yaitu sebesar 4,56 \%. Inflasi tertinggi adalah pada tahun 2014 yaitu dengan tingkat inflasi sebesar 7,54 \%. Pertumbuhan ekonomi rata - rata adalah sebesar 5,03\% dengan tingkat pertumbuhan terendah adalah pada tahun 2015 yaitu sebesar 4,88\% dan tertinggi adalah pada tahun 2018 yaitu sebesar 5,17. Pada tingkat suku Bunga SBI rata - rata adalah sebesar 4,41\% dimana tingkat bunga terendah adalah pada tahun 2019 yaitu sebesar 6,42 $\%$.

\section{Uji Normalitas dan Penyimpangan Asumsi Klasik}

Data awal yang digunakan pada penelitian ini yang berjumlah 162 data atau observasi dan hasilnya adalah data tidak terdistribusi secara normal. Melalui tahap screning data dengan mengeluarkan data sebanyak 8 dikeluarkan dan menyisakan 154 observasi menunjukkan data terdistribusi secara normal. Pembuktian ini ditandai dengan pengujian grafik $(P-P$ Plot dan Histogram) yang memenuhi kritieria normalitas. Berdasarkan uji Kolmogorov Smirnov sebesar 0,085 yang mana nilai signifikansi tersebut lebih besar dari nilai signifikansi yang telah ditentukan yaitu 0,05 .

Hasil pengujian penyimpangan asumsi klasik menunjukkan bahwa model tidak terjadi penyimpangan multikolinearitas yang ditandai dengan nilai VIF dibawah 10 yaitu $: 1,335 ; 1,038 ; 1,255 ; 5,086 ; 2,267$ dan 4,476 dan nilai tolerance diatas 0,1 yaitu 0,749 ; 0,$963 ; 0,797 ; 0,197 ; 0,441$ dan 0,223 . Grafik scatterplot tidak membentuk pola yang khusus atau jelas serta uji pada uji glejsyer sig diatas 0,05 , hal ini menunjukkan data tidak 
terjadi penyimpangan heteroskedastisitas. Nilai durbin Watson sebesar 1,847 yang mana nilai tersebut berada pada interval 1,66 sampai dengan 2,34 atau masuk pada kriteria tidak terjadi autokorelasi. Hasil pengujian Anova didapatkan nilai $\mathrm{F}$ hitungnya sebesar 2,887 nilai probabilitas adalah 0,011 . Hasil ini dikatakan bahwa permodelan yang dibangun memenuhi kriteria fit.

Tabel 2 : Perhitungan Regresi

\begin{tabular}{|c|c|c|c|c|c|c|c|c|}
\hline \multirow{2}{*}{\multicolumn{2}{|c|}{ Model }} & \multirow{2}{*}{\multicolumn{2}{|c|}{$\begin{array}{c}\text { Unstandardized } \\
\text { Coefficients }\end{array}$}} & \multicolumn{5}{|l|}{ Coefficients $^{a}$} \\
\hline & & & & \multirow{2}{*}{$\begin{array}{c}\text { Standardized } \\
\text { Coefficients } \\
\text { Beta }\end{array}$} & \multirow[t]{2}{*}{$\mathrm{t}$} & \multirow[t]{2}{*}{ Sig. } & \multicolumn{2}{|c|}{$\begin{array}{c}\text { Collinearity } \\
\text { Statistics }\end{array}$} \\
\hline & & B & Std. Error & & & & Tolerance & VIF \\
\hline \multirow{7}{*}{1} & (Constant) &,- 335 & 2,621 & &,- 128 & ,899 & & \\
\hline & ROE &, 008 & ,003 & ,247 & 2,740 & ,007 &, 749 & 1,335 \\
\hline & LDR & ,0002 &, 002 & 011 &, 135 & ,893 &, 963 & 1,038 \\
\hline & NIM &,- 001 & 015 &,- 004 &,- 046 & 963 & 797 & 1,255 \\
\hline & Inflasi &,- 129 &, 056 &,- 408 & $-2,316$ & 022 &, 197 & 5,086 \\
\hline & pertumb &, 169 & ,488 & ,041 & ,346 &, 730 &, 441 & 2,267 \\
\hline & Bunga & ,057 &, 041 & ,230 & 1,395 &, 165 & ,223 & 4,476 \\
\hline
\end{tabular}

a. Dependent Variable: R_Saham

Berdasarkan hasil print out spss dapat disajikan persamaan sebagai berikut $\mathrm{RS}=-0,335+0,008 \mathrm{ROE}+0,0002 \mathrm{LDR}-0,001 \mathrm{NIM}-0,129$ Inflasi + 0,169 Pertumbuhan $+0,057$ bunga

Return on equity (ROE) Perbankan Go Public di Indonesia mempunyai pengaruh positif signifikan terhadap retrun saham dengan koefisien regresi sebesar 0,008. Hal ini dapat diartikan bahwa setiap peningkatan return on equity (ROE) maka tingkat pengembalian saham (return saham) pada Bank Go Public di Indonesia mengalami peningkatan. Hipotesis 1 diterima, karena ditunjukkan dengan nilai probabilitas (sig) sebesar 0,007 yang mana nilai tersebut dibawah 0,05.

Hasil penelitian ini selaras dengan penelitian yang dilakukan oleh Rahmani (2019) dimana return on equity ( $R O E$ ) mempunyai pengaruh yang positif dan signifikan terhadap return saham perbankan. Kinerja perbankan yang ditunjukkan dengan kemampuan laba dari modal sendiri akan berdampak pada perolehan atau peningkatan pendapatan dari investor melalui return saham perbankan (Hendayana dan Nurlina, 2020). Lebih lanjut menurut Hendayana dan Nurlina (2020) perbankan yang mampu meningkatkan pendapatan bunga dari modal sendiri memberikan informasi yang positif bagi investor, sehingga saham yang diperdagangkan oleh perbankan tersebut lebih banyak permintaan, sehingga berdampak pada peningkatan return saham perbankan.

Loan to deposit ratio (LDR) Bank Go Public di Indonesia mempunyai pengaruh negatif dan tidak signifikan terhadap return saham dengan koefisien regresi sebesar 0,0002 . Hal ini dapat diartikan bahwa setiap peningkatan loan to deposit ratio $(L D R)$ tidak berdampak terhadap peningkatan return saham pada Bank Go Public di Indonesia atau sebaliknya setiap penurunan loan to deposit ratio (LDR) juga tidak perdampak pada penuunan return saham. Hipotesis 2 ditolak, karena dibuktikan dengan nilai probabilitas (sig) sebesar 0,893 yang mana nilai tersebut diatas 0,05 .

Hasil penelitian ini sejalan dengan penelitian yang dilakukan oleh Jaya (2015) dimana loan to deposit ratio (LDR) tidak berdampak pada return saham perbankan. Investor cenderung kurang memperhatikan tingkat pemberian kredit dari perbankan kepada para debiturnya (Purnamasari dkk, 2017). Keberanian bank dalam menyalurkan kredit atau pendanaan kepada debitur tidak memberikan informasi bahwa perbankan tersebut lebih unggul dan lebih dipercaya oleh masyarakat atau diabaikan oleh investor. 
Sejalan dengan hal tersebut Setyarini dan Rahyuda (2017) peningkatan pemberian kredit atau penurunan tidak memberikan signal positif ataupun negatif terhadap para investor untuk memiliki saham, sehingga loan to deposit ratio tidak berdampak pada tingkat kembalian atau return saham perbankan.

Net interest margin (NIM) Perbankan Go Public di Indonesia mempunyai pengaruh negatif tidak signifikan terhadap retrun saham dengan koefisien regresi sebesar - 0,001. Hal ini dapat diartikan bahwa setiap peningkatan net interest margin (NIM) maka tingkat kembalian (return saham) pada Bank Go Public di Indonesia tidak mengalami penurunan (tidak terbukti). Hipotesis 3 ditolak, karena ditunjukkan dengan nilai probabilitas (sig) sebesar 0,963 yang mana nilai tersebut diatas 0,05 .

Hasil penelitian ini sejalan dengan penelitian yang dilakukan oleh Dewi (2019), yaitu ada pengaruh yang negatif namun tidak signifikan dari net interest margin (NIM) terhadap return saham perbankan. Terjadinya peningkatan kemampuan bank atau meningkatknya rasio pendapatan bank dari bunga tidak berdampak langsung pada tingkat kembalian saham yang diterima investor (Syauta dan Widjaya, 2019). Investor tidak terlalu memperhatikan pendapatan bersih dari bunga, hal ini disebabkan karena sumber penerimaan bank tidak saja dari pendapatan bunga akan tetepi dari pos - pos lainnya seperti provisi kredit, penempatan pada pos investasi yang produktif (Yudistira dan Adiputra, 2020).

Inflasi di Indonesia mempunyai pengaruh negatif dan signifikan terhadap return saham dengan koefisien regresi sebesar 0,129. Hal ini dapat diartikan bahwa setiap peningkatan inflasi maka return saham pada Bank Go Public di Indonesia mengalami penurunan atau sebaliknya setiap penurunan inflasi akan meningkatkan return saham pada perbankan yang go public di Bursa Efek Indonesia. Hipotesis 4 diterima, karena dibuktikan dengan nilai probabilitas (sig) sebesar 0,022 yang mana nilai tersebut dibawah 0,05 .

Hasil penelitian ini selaras dengan penelitian yang dilakukan oleh Suryani dan Sudiartha (2018) dimana inflasi mempunyai pengaruh yang negatif tidak signifikan terhadap return saham perbankan. Dimana peningkatan inflasi di Indonesia tidak mempunyai terhadap penurunan return saham perbankan. Hal ini dipertegas oleh Yudistira dan Adiputra (2020) yaitu inflasi yang terjadi di negara tidak serta merta membuat para investor memindahkan sahamnya yang di perbankan ke sektor ekonomi yang lainnya seperti food and beverage, infrastruktur, otomatif, pertanian dan lain- lain, akan tetapi dipindahkan ke saham perbankan yang lainnya.

Pertumbuhan ekonomi mempunyai pengaruh positif tidak signifikan terhadap return saham dengan koefisien regresi sebesar 0,169. Hal ini dapat diartikan bahwa setiap peningkatan pertumbuhan maka return saham pada Bank Go Public di Indonesia tidak selalu mengalami peningkatan atau sebaliknya setiap pertumbuhan akan tidak mampu menurunkan return saham pada perbankan yang go public di Bursa Efek Indonesia. Hipotesis 5 ditolak, karena dibuktikan dengan nilai probabilitas (sig) sebesar 0,730 yang mana nilai tersebut diatas 0,05 .

Hasil penelitian ini sejalan dengan penelitian dari Sembiring 2017 menunjukkan bahwa pertumbuhan ekonomi yang di proksikan dengan product domestic bruto (PDB) tidak berpengaruh signfikan terhadap return saham. Hasil ini menunjukkan bahwa peningkatan pertumbuhan ekonomi tidak mempunyai dampak terhadap perolehan saham (return saham) perbankan (Adiyadnya dkk, 2016). Pertumbuhan ekonomi yang menurun tidak membuat investor berupaya menarik dana atau memindahkan dana yang disaham ke produk keuangan lainnnya atau valas. 
Tingkat suku bunga Bank Indonesia (SBI) mempunyai pengaruh positif tidak signifikan terhadap return saham dengan koefisien regresi sebesar 0,057. Hal ini dapat diartikan bahwa setiap peningkatan pertumbuhan bunga maka return saham pada Bank Go Public di Indonesia mengalami peningkatan atau sebaliknya setiap penurunan bunga akan menurunkan return saham pada perbankan yang go public di Bursa Efek Indonesia. Hipotesis 6 ditolak, karena dibuktikan dengan nilai probabilitas (sig) sebesar 0,165 yang mana nilai tersebut diatas 0,05 .

Hasil penelitian ini sejalan dengan penelitian Rizanti dan Husaini (2017) yang diperkuat oleh Suriyani dan Sudiartha (2018) dimana tingkat suku bunga SBI tidak berpengaruh terhadap return saham atau pengaruhnya adalah positif tidak signifikan. Hal ini menunjukkan bahwa peningkatan bunga bank yang ditentukan oleh Bank Indonesia tidak berdampak pada penurunan atau peningkatan return saham (Safuridar dan Asyuratama, 2018). Peningkatan bunga dipandang ada relevansinya dengan kemampuan ekonomi atau stabiltias ekonomi negara, sehingga investor kurang memperhatikan atau mengabaikan pertimbangan bunga dala menginvetasikan dananya di saham perbankan (Yudistira dan Adiputra, 2020).

\begin{tabular}{lcccc}
\multicolumn{5}{c}{ Tabel 3 : Koefisien Determinasi } \\
Model Summaryb \\
\hline Model
\end{tabular}

Besar variasi variabel tingkat kembalian saham (return saham) pada Bank Go Public di Indonesia yang dapat diterangkan oleh variasi variabel return on equity (ROE), loan to deposit ratio (LDR), net interest margin (NIM), inflasi, pertumbuhan ekonomi dan suku bunga SBI sebesar 10,5 persen, sedangkan sisanya sebesar 89,5\% dipengaruhi oleh variabel lain di luar model penelitian seperti faktor internal lainnya seperti return on asset, biaya operaional pendapatan operaisonal, non performing loan dan lain - lain ataupun dari faktor eksternal seperti kurs, kebijakan - kebijakan strategis dan lain sebagainya.

\section{PENUTUP}

Berdasarkan hasil penelitian menunjukkan bahwa return on equity (ROE) mempunyai pengaruh yang positif signifikan terhadap return saham pada Perbankan yang go public di BEI (Hipotesis 1 terbukti). Variable inflasi terbukti mempunyai pengaruh yang negative signifikan terhadap return saham pada perbankan yang go public di BEI (Hipotesis 4 terbukti). Variable loan to deposit ratio (LDR), net interest margin (NIM), pertumbuhan ekonomi dan suku bunga SBI $\left(\mathrm{H}_{2}, \mathrm{H}_{3}, \mathrm{H}_{5}\right.$ dan $\left.\mathrm{H}_{6}\right)$ tidak terbukti mempunyai pengaruh yang signifikan terhadap return saham perbankan yang go public di Bursa Efek Indonesia (BEI).

Berdasarkan hasil penelitian menunjukkan bahwa koefisien determinasi sebesar 10,5 persen yang tergolong rendah. Kedepan diharapkan penelitian untuk menambah variable atau mengganti variable penelitian yang bersifat fundamental. Variabel eksternal seperti inflasi, suku bunga, pertumbuhan ekonomi rawan terjadi multikolinearitas ditandai variance inflation factor yang tinggi. Kedepan perlu dilakukan formula atau pendekatan yang memasukkan pertumbuhan, bunga ataupun factor masing - masing dari perbankan terhadap factor eksternal tersebut (formula baru). Penelitian kedepan juga dapat 
mengembangkan dengan memasukkan variabel intervening atau moderating ke dalam model penelitian.

\section{DAFTAR PUSTAKA}

Adiyadnya, I Nyoman Sidhi. Artini, Luh Gede Sri dan Rahyuda, Henny. 2016. Pengaruh Beberapa Variabel Ekonomi Makro terhadap Profitabilitas dan Return Saham pada Industri Perbankan di BEI. E-Jurnal Ekonomi dan Bisnis Universitas Udayana. Vol 5 No 8 (2579 - 2608). Bali : FEB Udayana.

Amrillah, Muhammad Faisal. 2016. Pengaruh Nilai Tukar Rupiah (Kurs), Inflasi dan Pertumbuhan Ekonomi terhadap Return Saham Pada Perusahaan Perbankan Yang Terdaftar Di Bursa Efek Indonesia (BEI) Periode 2008-2014. Jurnal Valuta. Vol 2 No 2 (232 - 250). RIAU : FISIP

Antari, Ni Putu Hepy. Yuesti, Anik dan Dewi, Ni Putu Shinta . 2020. Pengaruh Kinerja Keuangan terhadap Return Saham pada Perusahaan Manufaktur yang terdaftar di Bursa Efek Indonesia Periode 2016-2018. Jurnal Kharisma. Vol. 2 No. 1. (212 -221). Denpasar : Universitas Mahasaraswati.

Arista, Desy dan Astohar. 2012. Analisis Faktor - Faktor Yang Mempengaruhi Return Saham (Kasus pada Perusahaan Manufaktur yang Go Public di BEI periode tahun 2005 - 2009). Jurnal Ilmu Manajemen dan Akuntansi Terapan. Vol. Nomor 1. $(1-15)$. Semarang : STIE Totalwin.

Astohar. 2013. Statistika Bisnis Kasus dan Solusi. Semarang : Penerbit Duta Nusindo.

Brigham, Eungene F. dan Houston, Joel F. 2001 Manajemen Keuangan. Jakarta : Erlangga

Ayem, Sri dan Wahyuni, Sri. 2017. Pengaruh Loan to Deposit Ratio, Capital Adequacy Ratio, Return On Asset dan Non Perfoming Loan terhadap Return Saham. Jurnal Akuntansi. Vol. 5 No. $(71-87)$. Yogyakarta : FE Universitas Sarjana Wiyata Taman Siswa

Dewi, Any Rustia. 2019. Pengaruh LDR, NIM Dan ROA terhadap Return Saham (Studi Kasus pada Bank Umum yang Terdaftar di Bursa Efek Indonesia 2014-2017). Jurnal Manajemen dan Kewirausahaan. Vol 7. No 1 (69-77). Malang : FEB Univ Merdeka.

Gantino, Rilla. Dan Maulana, Fahri. 2013. Pengaruh ROA, CAR, dan LDR terhadap Return Saham pada Perusahaan Perbankan yang Terdaftar di Bursa Efek Indonesia Periode 2008-2012. Proceeding Seminar Nasional \& Call For Papers (SCA-3).Vol 3. No 1 (1 -13) Purwokerto : FEB Universitas Jenderal Sudirman.

Ghozali, Imam. 2018. Aplikas Analisis Multivariate dengan Program IBM SPSS 25., Edisi 9. Semarang : Badan Penerbit Universitas Diponegoro.

Harahap, D. A., \& Hairunnisah, A. I. (2017). Pengaruh NPL, LDR, GCG, NIM, ROA, ROE, CAR, BOPO Terhadap Harga Saham Pada Perusahaan Perbankan yang Terdaftar di Bursa Efek Indonesia dari Tahun 2010-2014. Jurnal Dimensi.

Hasyim, Ali Ibarhim. 2017. Ekonomi Makro Edisi Pertama Cetakan ke-2. Depok: Kencana

Hendayana, Yayan dan Nurlina. 2020. Pengaruh Economic Value Added dan Profitabilitas terhadap Return Saham pada Perusahaan Sub Sektor Perdagangan Ritel yang 
Terdaftar di BEI Periode 2013-2017. Kinerja Jurnal Ekonomi Dan Bisnis. Vol. 2 No. 2 (34 - 43). Jakarta : Jur Manajemen FEB Universitas Islam AsSyafi'iyah.

Ismail. 2018. Manajemen Perbankan: Dari Teori Manuju Aplikasi, Ed 1 Cet 5. Jakarta: Prenada Media Group.

Jogiyanto. 2014. Teori Portofolio dan analisis Investasi. Edisi kelima. Yogyakarta : BPFE.

Juliana, Sanny Feria. Pahlevi, Cepi dan Amar, Yunus. 2019. Faktor-Faktor yang Mempengaruhi Return Saham perusahaan Perbankan yang Terdaftar di BEI Periode 2012-2017. JBMI. Vol. 15 No. 3 (305 - 321). Makasar : Universitas Hasanudin.

Kurniadi, Rintistya. 2012. Pengaruh CAR, NIM, LDR terhadap Return Saham Perusahaan Perbankan Indonesia. Accounting Analysis Journal. Vol 1. No 1 (8 - 11). Semarang : FE Unnes

Mankiw, Gregory N. 2006. Principles of Economics, Pengantar Ekonomi Makro. Edisi ketiga. Alih Bahasa Chriswan Sungkono. Salemba Empat: Jakarta

Maryanne. 2009. Ekonomi Makro. Jakarta : Salemba Empat

Nanga, Muana. 2007. Makro Ekonomi. Jakarta : Ghalia Indonesia

Nurlina. 2017. Pengaruh Nilai Tukar dan Suku Bunga Terhadap Harga Saham PT. Bank Rakyat Indonesia Tbk. Jurnal Samudra Ekonomika, VOL.1, NO. 1 (33-41).

Purnamasari, Diah. Nuraina, Elva dan Astuti, Elly. 2017. Pengaruh Capital Adequacy Ratio, Loan to Deposit Ratio dan Return on Asset terhadap Harga Saham Perusahaan Perbankan. Forum Ilmiah Pendidikan Akuntansi Vol 5 No 1 Oktober 2017 (264-277). Madiun : Universitas PGRI Madiun.

Rahmani, Nur Ahmadi Bi. 2019. Pengaruh Return On Assets (ROA), Return On Equity (ROE), Net Profit Margin (NPM), Dan Gross Profit Margin (GPM) Terhadap Harga Saham Perbankan Syariah Periode Tahun 2014-2018. KITABAH: Volume 3. No. 2 (110 - 120). Medan : FEBI Univ Islam Negeri Sumut

Safuridar, Zikra Asyuratama, 2018. Analisis Indikator Makro Ekonomi terhadap Harga Saham Sektor Perbankan. Jurnal Samudra Ekonomika, Vol. 2, No. 2 (137146). Jakrta : FE Universitas Samudra

Sambul, Sandro Heston. Murni, Sri. Tumiwa, Johan R.2016. Pengaruh Kinerja Keuangan Perbankan terhadap Harga Saham yang Ditawarkan di Bursa Efek Indonesia (Studi Kasus 10 Bank dengan Aset Terbesar). Jurnal Berkala Ilmiah Efisiensi. Vol 16 No. 02 (407 - 416). Manado : Feb Univ Samratulangi.

Sembiring, Masta. 2017. Analisis Pengaruh Pertumbuhan Ekonomi dan Inflasi terhadap Harga Saham pada Perusahaan Real Estate dan Property yang Terdaftar di Bursa Efek Indonesia Periode tahun 2011 - . 2015., Jurnal Bisnis., Vol 4 no 1

Setyarini, Ni Luh Putu Dewi Sunari dan Rahyuda, Henny. 2017. Pengaruh Kinerja Keuangan Terhadap Return Saham Perusahaan Perbankan Di Bursa Efek Indonesia (BEI). E-Jurnal Manajemen Unud, Vol. 6, No. 10 (5552-5579). Bali : FEB Universitas Udayana.

Sunaryo, Deni. 2020. Pengaruh Rasio Likuiditas, Aktivitas Dan Profitabilitas Terhadap 
Return Saham Sub Sektor Perbankkan BUMN di Bursa Efek Indonesia (BEI) Periode 2010-2018. Jurnal Manajemen Bisnis (JMB), Volume 33 No (25-38). Serang : FEB Univeristas Serang Raya

Sunardi, Harjono. 2010. Pengaruh Penilaian Kinerja dengan ROI dan EVA terhadap Return Saham pada perushaan yang Tergabung dalam LQ 45 di Bursa Efek Indonesia. Jurnal Akuntansi, Vol. 2, No. 1 (70-92).

Sugiyono. 2019. Metode Penelitian Kuantitatif Kualitatif dan R\&D. Jogyakarta : Alfabeta

Suriyani, Ni Kadek dan Sudiartha, Gede Mertha. 2018. Pengaruh Tingkat Suku Bunga, Inflasi Dan Nilai Tukar Terhadap Return Saham Di Bursa Efek Indonesia. EJurnal Manajemen Unud, Vol. 7, No. 6. (3172-3200). Bali : FE Unud.

Taswan. 2010. Manajemen Perbankan. Yogyakarta: Penerbit UPP STIM YKPN.

Yudistira, Elvin Ruswanda. Adiputra, I Made Pradana. 2020. Pengaruh Faktor Internal dan Ekternal Terhadap Harga Saham. Jurnal Ilmiah Akuntansi dan Humanika, Vol. 10 No. 2 (176 - 184). Bali : Universitas Pendidikan Ganesha.

Samuelson, Nordhaus. 2007. Ilmu Ekonomi Makro. Edisi Tujuh Belas. Jakarta: Media Global Edukasi

Zakiyah, Tuti. 2019. Pengaruh Faktor-Faktor Ekonomi Makro Terhadap Return Saham Dengan Profitabilitas Sebagai Variabel Intervening Pada Perusahaan Perbankkan Peraih Indonesia Banking Award (Iba) Tahun2018. Baabu Al-Ilmi. Vol.4 No.1 (89 - 119). : STIE Putra Bangsa. 